\title{
Frequency of incidental liver and renal masses accompanying adrenal incidentalomas
}

\section{Adrenal insidentalomaya eşlik eden karaciğer ve renal kitlelerinin sıklığı}

Narin Nasiroglu Imga, Yasemin Tutuncu, Mustafa Unal, Mazhar Muslum Tuna, Bercem Aycicek, Serhat Isik, Dilek Berker, Serdar Guler

Saglık Bilimleri University, Ankara Numune Education and Research Hospital Department of Endocrinology and Metabolism, 06100, Ankara, Turkey

Geliş Tarihi: 16.02.2018～Kabul Tarihi: 13.03 .2018

Doi: 10.21601/ortadogutipdergisi.395907

\begin{abstract}
Aim: An adrenal incidentaloma (AI) is an adrenal mass incidentally found on an imaging study that was not performed to diagnose an adrenal problem. Incidental hepatic and renal masses are often seen in abdominal imaging; however, for this research we aimed to determine the frequencies and kinds of hepatic and renal incidental masses in patients with AIs.

Material and Method: A retrospective evaluation of 381 AI patients (245 females and 136 males) and 285 control subjects (168 females and 117 males) was conducted. The adrenal masses were divided into two groups according to the Hounsfield unit (HU) scale ( $\leq 10$ or $>10$ ) and classified as bilateral, right, or left sided. Hepatic or renal incidental masses and those with both were compared between AI patients and controls also; comparison was made within AI patients.

Results: The incidental renal mass frequency and both hepatic and renal incidental masses frequency were found to be higher in the AI group than in the controls. In those AI patients who had unilateral, bilateral, and left sided adrenal masses $>10 \mathrm{HU}$, the frequencies of both hepatic and renal incidental masses were found to be greater than in the AI patients with masses $\leq 10 \mathrm{HU}$ ( $\mathrm{p}=0.001,0.049$, and 0.001 , respectively).

Conclusion: In AI patients with adrenal masses $>10 \mathrm{HU}$, due to the increased frequencies of both hepatic and renal incidental masses, physicians should evaluate these cases carefully. Additional large studies are needed to define the incidence and follow-up of AI patients with hepatic and renal incidentalomas.
\end{abstract}

Keywords: Adrenal incidentalomas, renal mass, liver mass 


\section{Öz}

Amaç: Adrenal insidentaloma (AI) adrenal dışı bir problem nedeniyle yapılan görüntüleme yöntemleri sırasında tesadüfen saptanan adrenal beze ait kitlelerdir. Karaciğer ve renal kitleler rastlantısal olarak abdomene ait görüntülemelerde görülebilirler. Bu nedenle bu çalışmamızda AI hastalarında eş zamanlı görülebilen rastlantısal hepatik ve renal kitlelerin sıklı̆̆ını ve çeşitlerini saptamayı amaçladık.

Gereç ve Yöntem: Retrospektif olarak 381 AI hastası (245 kadın ve 136 erkek) ve 285 kontrol bireyin (168 kadın ve 117 erkek) değerlendirilmesi yapıldı. Adrenal kitleler Hounsfield unit (HU) ölçeğine ( $\leq 10$ veya $>10)$ göre iki gruba ayrıldı ayrıca bilateral, sağ ve sol taraf kitleleri olarak sınıflandırıldı. Karaciğer veya renal kitleleri ya da her ikisi birlikte olanlar, hasta ile kontroller arasında ve ayrıca AI hastalarında kendi içerisinde karşılaştırıldı.

Bulgular: Renal kitlesi olanların sıklığı ile birlikte hepatik ve renal kitlesi olanların sıklığı hasta grubunda kontrol grubuna göre daha yüksek bulundu. Hasta grubunda adrenal kitle $>10$ HU olanlarda tek taraflı, bilateral ve sol taraflı hepatik ve renal rastlantısal kitle sıklığı adrenal kitle $\leq 10 \mathrm{HU}$ olan gruba göre daha yüksek saptand $1(\mathrm{p}=0.001$, 0.049 ve 0.001 ; sirasiyla).

Sonuç: Adrenal kitle > $10 \mathrm{HU}$ olan AI hastalarında, hem hepatik hem de böbrek kitle sıklığının artması nedeniyle klinisyenler bu vakaları dikkatle değerlendirmelidir. İnsidental karaciğer ve renal kitlesi olan AI hastalarının görülme sıklığını belirlemek ve uzun dönem takipleri için geniş çalışmalara ihtiyaç vardır.

Anahtar Kelimeler: Adrenal insidentaloma, Böbrek kitlesi, Karaciğer kitlesi

\section{Introduction}

I An adrenal incidentaloma (AI) is an adrenal mass that is found on an imaging study when investigating causes of abdominal or back pain not apparently related to an adrenal problem. It can be benign or malignant; however, the origin of an $\mathrm{AI}$ is usually the adrenal cortex, medulla, or extra-adrenal tissue [1]. In clinical practice, the widespread use of advanced imaging techniques, such as computed tomography (CT) and magnetic resonance imaging (MRI), has led to an increase in the incidence of AIs. In previous studies, the prevalence of AIs has been reported to be $2.3 \%$ in autopsy series and $0.5-2 \%$ in abdominal CT scans [2]. Radiological investigations have suggested that the prevalence of AIs increases with age; around $0.2 \%$ in young subjects compared with $6.9 \%$ in the elderly $[3,4]$. There is strong proof that most AIs are benign adrenocortical adenomas, and tend to be asymptomatic and nonfunctional [5]. In the assessment of benign and malignant AIs, measuring the X-ray absorption of tissues in a CT can assess the tissue density, which allows the calculation of the tissue attenuation as measured in HU. For a non-contrast $\mathrm{CT}$, an HU of $\leq 10$ is the most widely used threshold value for the diagnosis of a benign adrenal adenoma [6].
Accidentally detected liver masses, without liver specific symptoms, have been called liver or hepatic incidentalomas. In autopsy series, benign liver masses were seen in up to $50 \%$ of the general population, while in CT scans, the incidence of hepatic incidentalomas was $15 \%$ [7]. Hepatic incidental masses are often benign lesions, but because of the possibility of a primary or secondary malignant tumor of the liver, particularly in patients with a history of malignancy or a suspected diagnosis of hepatocellular adenoma, surgical resection is commonly indicated [8].

Incidental renal masses can be seen in various abdominal imaging methods. Due to the prevalence of renal cysts and incidence of renal cell carcinoma increasing with age, the frequency of incidental renal masses tends to increase in the older population $[9,10]$. Although the incidental detection of a renal mass can lead to the fortuitous diagnosis of renal cell cancer (RCC), these masses are commonly benign [11]. Previously published reports of autopsy series using common imaging methods revealed that $67-74 \%$ of RCCs remained undetected, while $8.9-20.0 \%$ of undiagnosed RCCs were responsible for mortality [12,13]. For these reasons, the evaluation of these incidental masses is of particular concern. 
The primary end point of this study was to investigate the frequencies and kinds of incidental hepatic and renal masses in AI patients. The second end point was to determine if the results indicated a significant frequency of these masses with regard to the relationships and features that could be extrapolated to the entire group of AI patients.

\section{Material and Method}

A retrospective evaluation of 381 AI patients and 285 controls was conducted between June 2009 and December 2015 at Ankara Numune Education and Research Hospital. Consecutively followed AI patients from the Department of Endocrinology, without any known renal or hepatic diseases, were included in this study. The controls were chosen randomly from healthy patients who underwent contrast-enhanced abdominal CT imaging for abdominal and/or back pain that were admitted to our hospital in recent years. For all of the participants (patients and controls], the height, weight, and body mass index (BMI) were evaluated. Those individuals with previous or concurrent histories of any known malignancy or with diseases known to cause renal or hepatic masses were excluded from this research.

For the AI patients, the adrenal masses were divided into two groups based on the Hounsfield unit scale $(\leq 10$ or $>10$ $\mathrm{HU})$ using abdominal CT scans in a non-contrast series. If the adrenal mass density was greater than 10 , a relative contrast washout $>40 \%$ and an absolute contrast washout $>60 \%$ suggested that the lesion was benign (accepted values). Additionally, the AI patients were classified as unilateral (left or right) or bilateral according to the side on which the mass was located.

Renal masses were classified as cystic or solid lesions, and also evaluated for evidence of fat, septation, calcification, and wall thickness. The liver masses were grouped as hemangiomas, cysts, adenomas, or cystadenomas according to recent renal and hepatic incidentaloma studies [14]. Incidentaloma comparisons were made between the adrenal, hepatic, and renal masses. Those patients who had both hepatic and renal incidental mases were described as such.

Hormone excess assessments were conducted in the AI patients. Using a $1 \mathrm{mg}$ overnightdexamethasone suppression test, the exclusion of autonomous cortisol secretion was made with a post-dexamethasone serum cortisol level $\leq 1.8$ $\mu \mathrm{g} / \mathrm{dl}$. The exclusion of pheochromocytoma was made by measuring the urinary fractionated metanephrines.
In those patients with concomitant hypertension or unexplained hypokalemia, the aldosterone/renin ratio was used to exclude primary aldosteronism. Those patients exhibiting these exclusion criteria were considered to have nonfunctioning adenomas.

\section{Ethic Committee:}

The study approved by the Local Ethics Committee of the Ankara Numune Education and Research Hospital.

Statistical Analyses: The SPSS (version 19.0; SPSS Inc., Chicago, IL, USA) statistical program was used for performed the statistical analysis of data of the study. The relevance to normal distribution of the data was evaluated by the Kolmogorov-Smirnov and Shapiro-Wilk tests. In comparing continuous variables that are in accordance with normal distribution, the normal student's t-test was used, and the data was expressed in terms of the average \pm standard deviation. In the comparison of continuous variables that are not in accordance with the normal distribution, the Mann-Whitney $U$ and KolmogorovSmirnov tests were used as appropriate. Pearson's chisquared and Fisher's exact tests were used to compare categorical data. Values were expressed in numbers and percentages. P levels of $<0.05$ were accepted as statistically significant.

\section{Results}

The general demographic characteristic of the AI patients and controls are summarized in Table 1. The AI group consisted of 245 females and 136 males, while the control group included 168 females and 117 males $(p=0.159)$. No statistically significant differences were found in terms of the age, height, weight, or BMI between the controls and AI patients ( $p=0.104,0.377,0.064$, and 0.317 , respectively). In the AI group, the frequencies of incidental renal masses and both hepatic and renal incidental masses were higher than in the control subjects ( $\mathrm{n}=111$ and $16.7 \%$ vs. $\mathrm{n}=61$ and $9.2 \%, \mathrm{n}=39$ and $5.9 \%$ vs. $\mathrm{n}=7$ and $1.1 \% ; \mathrm{p}=0.015$ and $<0.001$, respectively); however, the incidental hepatic mass frequency was not significantly different between the controls and AI patients $(n=14$ and $2.1 \%$ vs. $n=26$ and $3.9 \% ; \mathrm{p}=0.304)$. Thirty-one AI patients underwent adrenalectomies ( $8.1 \%$ of all AI patients), with the removal of $45.1 \%$ cortical adenomas, $6.5 \%$ adrenal hyperplasias, $29.0 \%$ pheochromocytomas, $12.9 \%$ adrenal cysts, and $6.5 \%$ cortical carcinomas. 
Table 1. General demographic data of controls and patients with adrenal incidentalomas

\begin{tabular}{|l|c|c|c|}
\hline & $\begin{array}{c}\text { Controls } \\
(\mathbf{n = 2 8 5})\end{array}$ & $\begin{array}{c}\text { AIs Patients } \\
(\mathbf{n}=\mathbf{3 8 1})\end{array}$ & $\mathbf{p}$ \\
\hline $\begin{array}{l}\text { Female (n) } \\
\text { Male (n) }\end{array}$ & $168(25.2 \%)$ & $245(36.8 \%)$ & 0.159 \\
\hline Age (years) & $117(17.6 \%)$ & $136(20.4 \%)$ & \\
\hline Height (cm) & $56.0(35-87)$ & $57.0(18-88)$ & 0.104 \\
\hline Weight (kg) & $164.0(147-196)$ & $165.0(140-182)$ & 0.377 \\
\hline BMI (kg/m2) & $76.0(50-102)$ & $79(45-103)$ & 0.064 \\
\hline $\begin{array}{l}\text { Hepatic incidental } \\
\text { mass (n) }\end{array}$ & $14(2.1 \%)$ & $26(3.9 \%)$ & 0.304 \\
\hline Renal incidental mass (n) & $61(9.2 \%)$ & $111(16.7 \%)$ & 0.015 \\
\hline $\begin{array}{l}\text { Both hepatic and renal } \\
\text { incidental mass (n) }\end{array}$ & $7(1.1 \%)$ & $39(5.9 \%)$ & $<0.001$ \\
\hline \multicolumn{2}{|l|}{ BMI. Body Mass Index AIs: Adrenal incidentalomas } & $28.3(22.8-40.0)$ & 0.317 \\
\hline
\end{tabular}

BMI: Body Mass Index AIs: Adrenal incidentalomas

The natures of the hepatic masses were compared between the controls and AI patients. The frequencies of the hepatic cysts $[\mathrm{n}=9(34.6 \%)$ vs. $\mathrm{n}=23(47.9 \%)]$, hemangiomas $[n=15(57.7 \%)$ vs. $n=23(47.9 \%)]$, and solid masses $[n=2$ $(7.7 \%)$ vs. $\mathrm{n}=2(4.2 \%)]$ were not found to be significantly different $(\mathrm{p}=0.499)$. With regard to the nature of the renal masses in the controls and AI patients, the frequencies of the simple renal cysts $[\mathrm{n}=59(85.5 \%)$ vs. $\mathrm{n}=97(85.2 \%)]$, solid renal masses $[\mathrm{n}=4(5.8 \%)$ vs. $\mathrm{n}=11(9.1 \%)]$, and complex cystic renal masses $[\mathrm{n}=6(8.7 \%)$ vs. $6(5.8 \%)]$ were not significantly different $(\mathrm{p}=0.126)$. Furthermore, the right sided and left sided AI mass sizes, mass volumes, and mass HU were investigated (Table 2), but no significant differences were found $(22.7 \pm 8.3 \mathrm{~mm}$ vs. $20.8 \pm 8.2 \mathrm{~mm}, 8.7 \pm 8.6 \mathrm{~cm} 3$ vs. $7.2 \pm 8.6 \mathrm{~cm} 3,7.7 \pm 11 \mathrm{HU}$ vs. $10.7 \pm 7.5 \mathrm{HU} ; \mathrm{p}=0.965,0.501$, and 0.812 , respectively). In the AI patients, comparisons were made between the right sided, left sided, and bilateral adrenal masses and the incidental hepatic mass frequency [9 (5.9\%) vs. $11(6.1 \%)$ vs. $6(12.8 \%) ; \mathrm{p}=0.225]$, incidental renal mass frequency [45 (11.8\%) vs. $51(13.4 \%)$ vs. 15 (3.9\%); p=0.877], and both hepatic and renal incidental masses frequency [13 $(3.4 \%)$ vs. $20(5.2 \%)$ vs. $6(1.6 \%) ; p=0.618]$, which were not found to be significantly different (Figure 1).
Table 2. The characteristic features of adrenal masses between right and left sided adrenal incidentalomas in AIs patients

\begin{tabular}{|l|c|c|c|}
\hline & $\begin{array}{c}\text { Right side adrenal } \\
\text { incidentaloma }\end{array}$ & $\begin{array}{c}\text { Left side adrenal } \\
\text { incidentaloma }\end{array}$ & $\mathbf{p}$ \\
\hline Size (mm) & $22.7 \pm 8.3$ & $20.8 \pm 8.2$ & 0.965 \\
\hline Volume (cm3) & $8.7 \pm 8.6$ & $7.2 \pm 8.6$ & 0.501 \\
\hline Mass HU & $7.7 \pm 11$ & $10.7 \pm 7.5$ & 0.812 \\
\hline
\end{tabular}

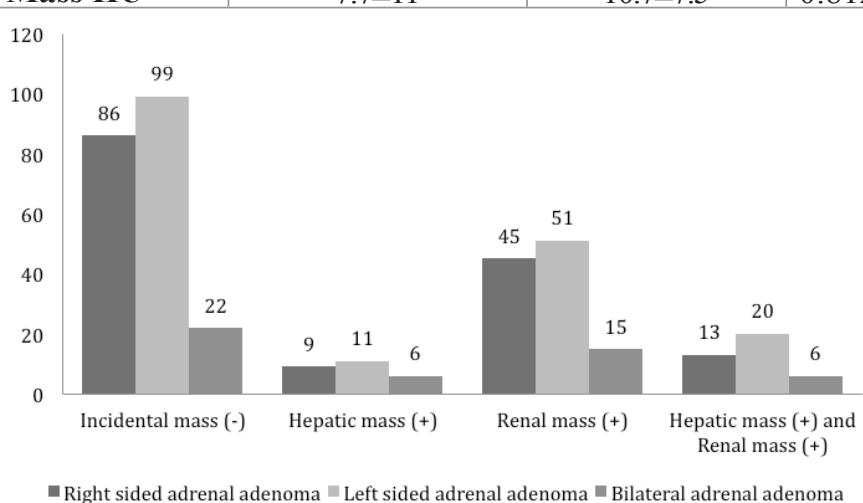

Figure 1. Comparison of localizations of adrenal incidental masses with hepatic and renal incidental mass ability in AIs patients $(\mathrm{p}=0.571)$ The hepatic and/or renal mass frequencies were also investigated in those patients with unilateral and bilateral adrenal adenomas according to masses $\leq 10 \mathrm{HU}$ and $>10$ $\mathrm{HU}$ in the abdominal CT scans (Table 3). In the unilateral adrenal adenoma group, between masses $\leq 10 \mathrm{HU}$ and masses $>10$ HU no statistically significant difference was found with regard to the incidental hepatic mass or incidental renal mass groups, but the frequency of both hepatic and renal incidental masses was greater in the unilateral adrenal adenoma $>10$ HU group $(p=0.001)$. However, those patients with bilateral incidental adrenal masses $>10 \mathrm{HU}$ had a higher frequency of both hepatic and renal incidental masses $(p=0.049)$. In those patients with unilateral adrenal masses, the right side and left side mass sizes $(\leq 10$ and $>10 \mathrm{HU}$ ) were compared with regard to the frequencies of hepatic and/or renal incidental masses (Table 4). In those patients, the frequency of both hepatic and renal incidental masses was higher in the patients with left sided AI masses of $>10 \mathrm{HU}$, when compared to those with masses $\leq 10 \mathrm{HU}(p=0.001)$.

Table 3. Comparison of hepatic and renal incidental mass availability according to adrenal adenoma HU in unoperated patients with adrenal incidentalomas

\begin{tabular}{|c|c|c|c|c|c|c|}
\hline 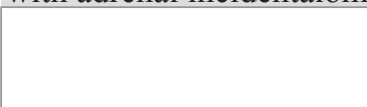 & $\begin{array}{c}\text { Unilateral } \\
\text { adenoma HU } \\
(n=204)\end{array}$ & $\begin{array}{c}\text { Unilateral ad- } \\
\text { enoma } H U>10 \\
(n=136)\end{array}$ & $\begin{array}{c}\text { Bilateral adenoma } \\
\text { HU } \leq 10(n=22)\end{array}$ & $\begin{array}{c}\text { Bilateral adenoma } \\
\text { HU }>10(n=19)\end{array}$ & p1 & p2 \\
\hline Hepatic incidental mass (+) & $13(3.8 \%)$ & $7(2.1 \%)$ & $2(4.9 \%)$ & $4(9.8 \%)$ & $0.638 \#$ & $0.262 *$ \\
\hline Renal incidental mass $(+)$ & $59(17.4 \%)$ & $43(12.6 \%)$ & $3(7.3 \%)$ & $6(14.6 \%)$ & $0.595 \#$ & $0.157^{*}$ \\
\hline $\begin{array}{l}\text { Both hepatic and renal } \\
\text { incidental mass }(+)\end{array}$ & $11(3.2 \%)$ & $22(6.5 \%)$ & $1(2.4 \%)$ & $5(12.2 \%)$ & $0.001 \#$ & $0.049 *$ \\
\hline
\end{tabular}


Table 4. Comparison of right and left adrenal adenoma side and adenoma HU with hepatic and renal incidental mass availability in unilateral AIs patients

\begin{tabular}{|c|c|c|c|c|c|c|}
\hline & $\begin{array}{c}\text { Right side } \\
\text { adenoma } H U \leq 10 \\
(n=103)\end{array}$ & $\begin{array}{l}\text { Right side ad- } \\
\text { enoma HU>10 } \\
(n=73)\end{array}$ & $\begin{array}{c}\text { Left side adenoma } \\
\mathrm{HU} \leq \mathbf{1 0} \\
(\mathrm{n}=117)\end{array}$ & $\begin{array}{c}\text { Left side adenoma } \\
\text { HU>10 } \\
(n=70)\end{array}$ & p1* & p2* \\
\hline Hepatic incidental mass (+) & $6(3.4 \%)$ & $8(4.5 \%)$ & $7(3.7 \%)$ & $8(4.3 \%)$ & 0.215 & 0.185 \\
\hline Renal incidental mass $(+)$ & $26(14.8 \%)$ & $20(11.4 \%)$ & $33(17.6 \%)$ & $15(8.0 \%)$ & 0.749 & 0.305 \\
\hline $\begin{array}{l}\text { Both hepatic and renal } \\
\text { incidental mass }(+)\end{array}$ & $7(4.0 \%)$ & $9(5.1 \%)$ & $5(2.7 \%)$ & $13(7.0 \%)$ & 0.208 & 0.001 \\
\hline
\end{tabular}

\section{Discussion}

With the wide availability and improvements in imaging methods and the increasing use of scanning tools, the detection of incidental masses will continue to rise. It has been reported that renal and hepatic cysts are the most commonly seen benign lesions, and that non-calcified pulmonary nodules and adrenal masses are the most frequently seen incidentalomas in abdominal CT scans [15]. In one systematic review assessing the frequency of incidental findings reported from diagnostic imaging techniques, the mean frequency of incidental findings in the genitourinary and gastrointestinal system was $24.9 \%$ [16]. For this research, we wanted to draw attention to incidental hepatic and renal masses in AI patients because the malign versions of these masses are the most commonly seen human malignancies detected using abdominal imaging methods. However, the frequency of incidental hepatic masses was not found to be different between the controls and AI patients. This may be related to the higher liver cancer incidence rate than that of RCC [17]. In our study, among the AI patients, the frequencies of incidental renal masses and both hepatic and renal incidental masses were found to be greater than in the controls. The increased frequency of both hepatic and renal incidental masses may be due to the elevated renal mass incidence.

The pathogenesis and molecular mechanisms of tumorigenesis of adrenocortical tumors remain controversial. Some researchers have suggested that adrenal carcinomas are the result of somatic mutations, arguing for the clonal expansion of a single transformed cell [18]. The wingless-type mouse mammary tumor virus integration site gene family (WNT) signaling pathway is expressed in the adrenal cortex, and is responsible for adrenocortical development and benign and malignant adrenal tumor progression [19]. In addition, the WNT signaling pathway is involved in normal embryonic development, and controls the homeostatic self-renewal of stem cells in adult stem cell maintenance [20]. It also plays a pathological role in numerous human cancers, likely via mutations that activate the transcriptional response of the WNT pathway. Moreover, the inhibition of WNT signaling can have a stimulatory effect on cell proliferation [21]. A homozygous deletion of the CXXC4 gene, which is a negative regulator of WNT signaling, has been described previously in an RCC tumor [22].

In patients with a genetic predisposition toward developing renal masses, the mechanisms are still unknown, but some genetic markers have been associated with renal cell tumors. For example, the dissection of the molecular biology pathways involving the Wilms' tumor protein-1 (WT1) and the von Hippel-Lindau (VHL) genes has been associated with the development of renal tumors [23]. In addition, elevated levels of the insulin-like growth factor receptor (IGFR) have been detected in various human tumors. The IGFR plays an essential role in the regulation of cell growth, protection from apoptosis, differentiation, and oncogenic transformation. Moreover, the WT1 and VHL tumor suppressors regulate IGFR gene expression. An impaired IGFR gene has been related to defective cell division, chromosomal instability, and an increased incidence of cancer [24].

In adrenocortical tumorigenesis, the origination of the growth of a polyclonal tumor may be reflected by the action of extrinsic factors, such as mitogens or growth factors (epidermal growth factor, fibroblast growth factor, and IGFR), which may increase cell proliferation [25]. Comparative genomic hybridization (CGH), a powerful technique for studying amplified DNA sequences, has revealed chromosomal areas that contain amplified cellular oncogenes [26]. In adrenocortical tumors, a positive 
correlation has been described between tumor size and CGH changes, suggestingthatchromosomalalterationsaccumulate during tumor progression. Chromosomal alterations have been observed in $28 \%$ of benign adrenocortical tumors [27]. CGH has been described in many human neoplasms, including adrenal, renal, and hepatocellular tumorigenesis [28]. We believe that these gene mechanisms may have affected the increased incidence of both hepatic and renal incidental masses in the AI patients.

Nickerson et al. [29] described disease-causing mutations in the Birt-Hogg-Dubé (BHD) gene, a novel kidney cancer gene associated with renal oncocytoma or chromophobe renal cancer, as helping to understand the role of folliculin in pathways common to lung, skin, and kidney tissue expression. In addition, the c-Jun transcription factor has been associated with several cellular mechanisms, including proliferation, survival, and transformation [30]. Tumor suppressor genes, such as $\mathrm{p} 53$, retinoblastoma, and $\beta$-catenin are frequently transformed; likewise, Ras and c-Myc oncogenes that regulate the proliferation or apoptosis of hepatocytes are often activated. It has been shown that the deletion of c-Jun dramatically affects liver tumor formation [31]. These mechanisms are reflected in our study, because among the AI patients with unilateral adrenal masses $>10 \mathrm{HU}$ and bilateral adrenal masses $>10$ $\mathrm{HU}$, the frequencies of both hepatic and renal incidental masses were higher. These findings suggest that adrenal masses $>10 \mathrm{HU}$ reflect a greater tumor load, inducing a higher prevalence of multiple incidental masses in the kidney and liver. Further genomic studies in patients with single or multiple incidental masses will help elucidate this association.

One related mechanism may be epidermal growth factor receptor (EGFR) overexpression. The EGFR has been demonstrated in many solid tumors, and contains an extracellular domain, a transmembrane spanning domain, and an intracellular tyrosine kinase domain [32]. It plays an essential role in tumorigenesis, with various human solid organ tumors overexpressing EGFR, including colon, lung, and renal cancer. Targeting the EGFR via the EGFR inhibitor tyrosine kinase for the treatment of anti-EGFR antibodies inhibits the growth of human renal cell carcinoma tumors [33] and hepatocellular carcinoma tumors [34]. In addition, angiogenesis has an important responsibility in tumor growth, progression, and invasiveness. Some studies have reported that the increased serum concentrations of angiogenesis markers, such as the vascular endothelial growth factor (VEGF), show an association with adrenal, hepatic, and renal tumors [3537]. Therefore, high serum concentrations of VEGF may result in the growth of these tumors. Large prospective genetic studies will illuminate the role of most genetic variants in the formation of incidentalomas in the general population. An understanding of the genetic pathways that originate most incidentalomas offers an occasion for the specific therapeutic management of patients with multiple incidentalomas.

Our study does have some limitations. For example, the same radiologist through all the study did not perform a review of the CT scans, and the hepatic and renal masses were not evaluated according to the HU. Because of the hepatic and renal masses are the most seen masses; the other abdominal masses were not evaluated in the slice of the CT scans. Molecular and genetic analyzes of these patients were not performed, but it was done better results could have been obtained. Another limitation was that the number of patients undergoing surgery was low, and for this reason a comparison was not made between those patients who were and were not operated on. Finally, a long-term follow up of these incidental masses could not be done, which would have given us better information in terms of the tumor progression.

\section{Conclusion}

An increased incidence of both hepatic and renal incidental masses was detected in the AI patients. We suggest that in AI patients with adrenal masses $>10 \mathrm{HU}$, due to this increased frequency, physicians should carefully evaluate these cases. To the best of our knowledge, this is the first report on the investigation of the frequency of incidental liver and renal masses in AI patients. Unfortunately, the overall lack of studies on this subject precludes making specific management recommendations. Larger studies are needed in the future to define the incidence and follow-up of AIs accompanied by hepatic and renal incidentalomas.

\section{Conflict of Interest: None declared.}

Financial Disclosure: The authors declared that this study has received no financial support. 


\section{References}

1. Fassnacht M, Arlt W, Bancos I, et al. Management of adrenal incidentalomas: European society of endocrinology clinical practice guideline in collaboration with the European network for the study of adrenal tumors. Eur J Endocrinol 2016;175:G1-34.

2. Barzon L, Sonino N, Fallo F, Palu G \& Boscaro M. Prevalence and natural history of adrenal incidentalomas. Eur J Endocrinol 2003; 149:273-85.

3. Kloos RT, Gross MD, Francis IR, Korobkin M, Shapiro B. Incidentally discovered adrenal masses. Endocr Rev 1995;16:460-84.

4. Herrera MF, Grant CS, Van Heerden JA, Sheedy PF, Ilstrup DM. Incidentally discovered adrenal tumors: an institutional perspective. Surgery 1991;110:1014-21.

5. Bovio S, Cataldi A, Reimondo G, et al. Prevalence of adrenal incidentaloma in a contemporary computerized tomography series. J Endocrinol Invest 2006;29:298-302.

6. Boland GW, Lee MJ, Gazelle GS, Halpern EF, McNicholas MM, Mueller PR. Characterization of adrenal masses using unenhanced CT: an analysis of the CT literature. Am J Roentgenol 1998;171:201-4.

7. Ehrl D, Rothaug K, Herzog P, Hofer B, Rau HG. "Incidentaloma" of the liver: management of a diagnostic and therapeutic dilemma. HPB Surg 2012;891787.

8. Zulke C, Loss M, Iesalnieks I, et al. Benign liver lesions: indication for surgery and postoperative results. Viszeralchirurgie-stuttgart 2004;39:86-97.

9. Luciani LG, Cestari R, Tallarigo C. Incidental renal cell carcinomaage and stage characterization and clinical implications: study of 1092 patients (1982-1997). Urology 2000; 56:58-62.

10. Terada N, Ichioka K, Matsuta Y, Okubo K, Yoshimura K, Arai Y. The natural history of simple renal cysts. J Urol 2002;167:21-3.

11. O’Connor SD, Pickhardt PJ, Kim DH, Oliva MR, Silverman SG. Incidental finding of renal masses at unenhanced CT: prevalence and analysis of features for guiding management. Am J Roentgenol 2011;197:139-45.

12. Wunderlich H, Schumann S, Jantitzky V, et al. Increase of renal cell carcinoma incidence in central Europe. European urology. 1998;33:538-41.

13. Hajdu SI, Berg JW, Foote FW Jr. Clinically unrecognized, silent renal-cell carcinoma in elderly cancer patients. J Am Geriatr Soc. 1970;18:443-449.
14. Hitzeman N, Cotton E. Incidentalomas: initial management. Am Fam Physician 2014;90:784-9.

15. Ekeh AP, Walusimbi M, Brigham E, Woods RJ, McCarthy MC. The prevalence of incidental findings on abdominal computed tomography scans of trauma patients. J Emerg Med 2010;38:484-9.

16. Lumbreras B, Donat L, Hernández-Aguado I. Incidental findings in imaging diagnostic tests: a systematic review. $\mathrm{Br} \mathrm{J}$ Radio 2010;83:276-89.

17. Torre LA, Bray F, Siegel RL, Ferlay J, Lortet $\square$ Tieulent J, Jemal A. Global cancer statistics, 2012. CA: a cancer journal for clinicians. 2015;65:87-108.

18. Bishop JM. Molecular themes in oncogenesis. Cell 1991;64:235-48.

19. Suwa T, Chen M, Hawks CL, Hornsby PJ. Zonal expression of dickkopf-3 and components of the Wnt signalling pathways in the human adrenal cortex. J Endocrinol 2003;178:149-58.

20. Austin TW, Solar GP, Ziegler FC, Liem L, Matthews W. A role for the Wnt gene family in hematopoiesis: expansion of multilineage progenitor cells. Blood 1997; 89:3624-35.

21. Taipale J, Beachy PA. The Hedgehog and Wnt signalling pathways in cancer. Nature 2001;411:349-54.

22. Kojima T, Shimazui T, Hinotsu S, et al. Decreased expression of CXXC4 promotes a malignant phenotype in renal cell carcinoma by activating Wnt signaling. Oncogene 2009;28:297-305.

23. Fleming S. Genetics of renal tumours. Cancer Metastasis Rev 1997;16:127-40.

24. Werner H, Sarfstein R. Transcriptional and epigenetic control of IGF1R gene expression: implications in metabolism and cancer. Growth Horm IGF Res 2014;24:112-8.

25. Mesiano S, Mellon SH, Jaffe RB. Mitogenic action, regulation, and localization of insulin-like growth factors in the humanetal adrenal gland. J Clin Endocrinol Metab 1993;76:968-76.

26. Kallioniemi A, Kallioniemi O-P, Sudar D, et al. Comparative genomic hybridization for molecular cytogenetic analysis of solid tumors. Science 1992;258:818-21.

27. Kjellman M, Kallioniemi OP, Karhu R, et al. Genetic aberrations in adrenocortical tumors detected using comparative genomic hybridization correlate with tumor size and malignancy. Cancer Res 1996;56:4219-23.

28. Knuutila S, Björkqvist AM, Autio K, et al. DNA copy number amplifications in human neoplasms: review of comparative genomic hybridization studies. Am J Pathol 1998;152:1107. 
29. Nickerson ML, Warren MB, Toro JR, et al. Mutations in a novel gene lead to kidney tumors, lung wall defects, and benign tumors of the hair follicle in patients with the Birt-Hogg-Dube syndrome. Cancer cell 2002;2:157-64.

30. Jochum W, Passegue E, Wagner EF. AP-1 in mouse development and tumorigenesis. Oncogene 2001;20: 2401.

31. Eferl R, Ricci R, Kenner L, et al. Liver tumor development: c-Jun antagonizes the proapoptotic activity of p53. Cell 2003;112:181-92.

32. Bargmann CI, Hung MC, Weinberg R. The neu oncogene encodes an epidermal growth factor receptor related protein. Nature 1986;319:226-30.

33. Prewett M, Rothman M, Waksal H, Feldman M, Bander NH, Hicklin DJ. Mouse-human chimeric anti-epidermal growth factor receptor antibody C225 inhibits the growth of human renal cell carcinoma xenografts in nude mice. Clin Cancer Res 1998;4:2957-66.

34. Huether A, Höpfner M, Baradari V, Schuppan D, Scherübl H. EGFR blockade by cetuximab alone or as combination therapy for growth control of hepatocellular cancer. Biochemical pharmacology 2005; $70: 1568-78$
35. Foltyn W, Strzelczyk J, Marek B, et al. The usefulness of determining the serum concentrations of vascular endothelial growth factor (VEGF) and its soluble receptor type 2 (sVEGF-2) in the differential diagnosis of adrenal incidentalomas. Endokrynol Pol 2012;63:22-8

36. Mukozu T, Nagai H, Matsui D, Kanekawa T, Sumino Y. Serum VEGF as a tumor marker in patients with $\mathrm{HCV}$-related liver cirrhosis and hepatocellular carcinoma. Anticancer Res 2013; 33:1013-21.

37. Takahashi A, Sasaki H, Kim SJ, et al. Markedly increased amounts of messenger RNAs for vascular endothelial growth factor and placenta growth factor in renal cell carcinoma associated with angiogenesis. Cancer Res 1994;54: 4233-7.

Corresponding Author: Narin Nasiroglu Imga, Saglık Bilimleri University, Ankara Numune Education and Research Hospital Department of Endocrinology, 06100, Ankara, Turkey

E-mail:xnarinx@yahoo.com 